\title{
Responsiveness of the corpus luteum of the rhesus monkey (Macaca mulatta) to gonadotrophin in vitro during spontaneous and prostaglandin $\mathrm{F}_{2 \alpha}$-induced luteolysis
}

\author{
F. J. Auletta, L. B. Kelm and M. J. Schofield \\ Department of Obstetrics and Gynecology and Biochemistry, University of Vermont College of Medicine, \\ Burlington, Vermont 05405-0068, USA
}

\begin{abstract}
The ability of luteal tissue from rhesus monkeys, collected from spontaneous and prostaglandin $\mathrm{F}_{2 \alpha}\left(\mathrm{PGF}_{2 \alpha}\right)$ induced luteolytic cycles, to secrete progesterone in response to hCG or dibutyryl cAMP in vitro was assessed. It was expected that the corpus luteum exposed to $\mathrm{PGF}_{2 a}$ would behave in a similar manner to the corpus luteum of normal cycles undergoing luteal regression. $\mathrm{PGF}_{2 \alpha}\left(10 \mathrm{ng} \mu \mathrm{l}^{-1} \mathrm{~h}^{-1}\right)$ or vehicle $\left(1 \mu \mathrm{h} \mathrm{h}^{-1}\right)$ was infused into the corpus luteum from 7 days after the preovulatory oestradiol surge. Lutectomy was performed at 2, 3 and 4 days after the start of the intraluteal infusion and at menses. Luteal progesterone content was determined and the secretion of progesterone in response to hCG (10 miu $\mathrm{ml}^{-1}$ ) or dibutyryl cAMP $\left(5 \mathrm{mmol} \mathrm{l}^{-}\right)$was evaluated in vitro. A third group of monkeys underwent lutectomy sequentially during the luteal phase and were grouped by luteal age from days after the preovulatory oestradiol surge: early luteal (days 4-6), midluteal (days 7-9), late luteal (days 10-14) and menses. Immediately before luteal excision, an ovarian venous blood sample was taken for progesterone determination. Approximately 2-5 mg of minced luteal tissue was incubated at $37^{\circ} \mathrm{C}$ in $2 \mathrm{ml}$ of Krebs-Ringer bicarbonate buffer for $2 \mathrm{~h}$ in the presence or absence of hCG or dibutyryl cAMP. In control and vehicle-infused monkeys, $\mathrm{hCG}$ caused an increase in luteal progesterone production during the mid-luteal and late luteal phases, but not at the early luteal phase or at menses; exposure to dibutyryl cAMP resulted in a significant increase in progesterone at all times except menses. The response of luteal tissue to hCG or dibutyryl cAMP progressively decreased as a function of luteal age. Luteal tissue treated with $\mathrm{PGF}_{2 a}$ in vivo also exhibited a decreased response to progesterone production stimulated by $\mathrm{hCG}$; that is, the response to $\mathrm{hCG}$ was inversely correlated with the duration of luteal infusion with $\mathrm{PGF}_{2 \alpha}$. This observation mimicked the events observed over the course of the normal or vehicle-infused luteal phase. The failure of hCG and dibutyryl cAMP to stimulate progesterone production at menses implies that once luteolysis is complete, the integrity of the steroidogenic response is unequivocally lost. The progressive decline in responsiveness to hCG further suggests that receptor loss is not a sudden event in the mechanism of $\mathrm{PGF}_{2 a}$-induced or spontaneous luteolysis, but a progressive process coincident with luteal ageing. These data strongly suggest that spontaneous and $\mathrm{PGF}_{2 a}$-provoked luteal regression are very similar with regard to progesterone content, basal synthesis and sensitivity to gonadotrophin and further support a physiological role for $\mathrm{PGF}_{2 \alpha}$ during luteolysis in primates.
\end{abstract}

\section{Introduction}

Observations in vivo and in vitro in most non-primate mammals indicate that luteolysis is due to uterine synthesis and release of prostaglandin $\mathrm{F}_{2 \alpha}\left(\mathrm{PGF}_{2 u}\right)$ and its subsequent transport via a countercurrent mechanism to the ovary (McCracken ef al., 1981). In nonhuman primates and women, $\mathrm{PGF}_{2 a}$ is not responsible for luteolysis as hysterectomy does not alter ovarian periodicity (Neill et al., 1969). It was suggested that the failure of systemically administered $\mathrm{PGF}_{2 a}$ to induce luteal regression in primates results from the resistance of the corpus luteum to $\mathrm{PGF}_{2 \alpha}$ except at specific times in its lifespan (Auletta and Flint, 1988) or to the rapid metabolism of $\mathrm{PGF}_{2 \alpha}$. However, $\mathrm{PGF}_{2 u}$ is luteolytic when infused directly and continuously at a physiological dose into the corpus luteum of rhesus monkeys (Auletta et al., 1984a; Zelinski-Wooten and Stouffer, 1990) and of marmoset monkeys (Hearn and Webley, 1987). PGF $2 u$ analogues also induce luteolysis in rhesus monkeys in early 
pregnancy (Wilks, 1980) and in cyclic marmosets (Summers et al., 1985). Furthermore, ovarian venous concentrations of the major blood metabolite of $\mathrm{PGF}_{2 \alpha^{\prime}}$ 13,14-dihydro-15-keto$\mathrm{PGF}_{2 \alpha}\left(\mathrm{DHK}-\mathrm{F}_{2 \alpha}\right)$, are significantly increased on the corpus luteum side during luteolysis, when compared with the contralateral effluent (Auletta et al., 1984b). This observation suggests luteal synthesis and metabolism of $\mathrm{PGF}_{2 a^{\prime}}$ first described by Wilks et al. (1972) and confirmed by Balmaceda ef al. (1979). Collectively, these studies suggest that PGF ${ }_{2 a}$ of intraluteal origin is luteolytic in primates and may represent the physiological luteolysin (Auletta, 1990; Michael et al., 1994).

The mechanism by which PGF $_{2 \alpha}$ causes luteal demise is still unknown. Studies in vitro using luteal tissue slices consistently demonstrate an inhibitory effect on gonadotrophin-stimulated progesterone production and cAMP formation (Stouffer et al., 1977; Hamberger et al., 1979; Dennefors et al., 1982). However, incubations of dispersed luteal cells have yielded contradictory results (Stouffer et al, 1979; Richardson and Masson, 1980; Michael et al., 1993). It appears that for $\mathrm{PGF}_{2 \alpha}$ to exhibit an antigonadotrophic effect, the integrity of the luteal tissue is vital. It has been postulated that this inhibitory action is directed through a complex of autocrine/paracrine events, including decreased gonadotrophin binding, gonadotrophin receptor loss, the impairment of post-cAMP-mediated steroidogenic events and apoptosis (Kenny and Robinson, 1986; Abayasekara et al., 1993; Michael et al., 1994).

The purpose of the present investigation was to assess the ability of the corpus luteum, resulting from spontaneous and $\mathrm{PGF}_{2 \alpha}$-induced luteolytic cycles, to secrete progesterone in vitro in response to hCG or dibutyryl cAMP. The hypothesis tested was that luteal tissue exposed to $\mathrm{PGF}_{2 \alpha}$ in vivo will respond in a similar manner as normal tissue undergoing luteal regression, thereby further strengthening the postulate that $\mathrm{PGF}_{2 \alpha}$ is the physiological luteolysin in primates.

\section{Materials and Methods}

\section{Animals}

Adult female rhesus monkeys (Macaca mulatta) with regular menstrual cycles were housed individually in an artificially illuminated $(06: 00-18: 00 \mathrm{~h})$, temperature $\left(20^{\circ} \mathrm{C}\right)$ and humidity $(30 \%)$ controlled room. They were fed commercially prepared monkey chow supplemented with fresh fruit. Water was available ad libitum. Vaginal inspection and lavage were performed every morning to detect the onset and duration of menstrual bleeding.

\section{Ethics of experimentation}

This investigation was approved by the University of Vermont Institutional Animal Care and Use Committee in accordance with all applicable federal and state laws and regulations.

\section{Blood sampling and hormone assays}

During the experimental cycles, daily peripheral blood $(2-3 \mathrm{ml})$ was drawn from either the saphenous or femoral vein to ascertain the day of the preovulatory oestradiol surge (this day was defined as day 0). All blood samples were collected in heparinized tubes between 07:00 and 10:00 $\mathrm{h}$ and the plasma was frozen $\left(-20^{\circ} \mathrm{C}\right)$ until measurement of oestradiol and progesterone by radioimmunoassay, as previously used in our laboratory (Auletta and Kelm, 1994). Briefly, the steroids were assayed, in at least duplicate, using radioimmunoassay kits (Leeco Diagnostics, Southfield, MI). Intra- and interassay coefficients of variation were $3.7 \%$ and $7.6 \%$ for progesterone, and $5.3 \%$ and $8.7 \%$ for oestradiol, respectively. Tissue protein was determined using the method of Bradford (1976) (Biorad Laboratories, Richmond, CA).

\section{Surgical model}

The Alzet pump-luteal cannula system used delivered $\mathrm{PGF}_{2 \alpha}$ or vehicle into the corpus luteum (Auletta et al., 1984a). A mid-ventral laparotomy was performed, under sterile conditions, using sodium pentobarbital anaesthesia $\left(20 \mathrm{mg} \mathrm{kg}^{-1}\right.$ body mass; Park Davis, St Louis, MO) and the ovary bearing the corpus luteum identified. The ovarian capsule adjacent to the corpus luteum was punctured with an 18 gauge needle, and a polyvinyl no. 2 cannula connected to an Alzet osmotic pump (Model 2001; Alza Corp, Palo Alto, CA) was inserted through the adjacent stroma directly into the corpus luteum and secured. Before closure, the pump was exteriorized in the subcutaneous flank. The cannula and pump were prefilled. The pump is designed to deliver $1 \mu \mathrm{l}$ solute $\mathrm{h}^{-1}$ for 7 days (volume capacity $170 \mu \mathrm{l})$.

\section{Experimental design}

Monkeys were intraluteally infused with $\operatorname{PGF}_{2 \alpha}\left(10 \mathrm{ng} \mu \mathrm{l}^{-1}\right.$ $\left.\mathrm{h}^{-1}\right)$ or vehicle $\left(1 \mu \mathrm{h}^{-1}\right.$, tham Itris hydroxymethyl aminomethane] buffer), both purchased from Sigma Chemical (St Louis, MO) from day 7 after the preovulatory oestradiol surge to the onset of menses. An ovarian venous blood sample $(2 \mathrm{ml})$ was taken for evaluation of progesterone before surgical placement of the cannula and lutectomy. A group of cyclic monkeys underwent lutectomy sequentially during the luteal phase: early luteal (days 4-6); mid-luteal (days 7-9); late luteal (days 10-14) and menses. These times were assigned in accordance with previous observed changes in progesterone concentrations (Auletta et al., 1984b).

After lutectomy, the corpus luteum was transported to the laboratory on ice in Krebs-Ringer bicarbonate buffer (KRB), trimmed of extraneous tissue and weighed. The tissue was divided into samples for histological studies, measurement of luteal progesterone and protein content and for in vitro incubation studies.

\section{Incubation conditions}

Minced luteal tissue was incubated at $37^{\circ} \mathrm{C}$ in $2 \mathrm{ml} \mathrm{KRB}$ ( $\mathrm{pH} 7.4$, plus $2 \mathrm{mg}$ glucose $\mathrm{ml}^{-1}$, gassed with $95 \% \mathrm{O}_{2}$ and $5 \%$ $\mathrm{CO}_{2}$ ) in a shaking waterbath for $2 \mathrm{~h}$. Luteal tissue was incubated, in at least duplicate, in the presence or absence of hCG or dibutyryl cAMP. At the end of the incubations, the tubes were snap frozen in a dry ice-acetone bath and the flask 


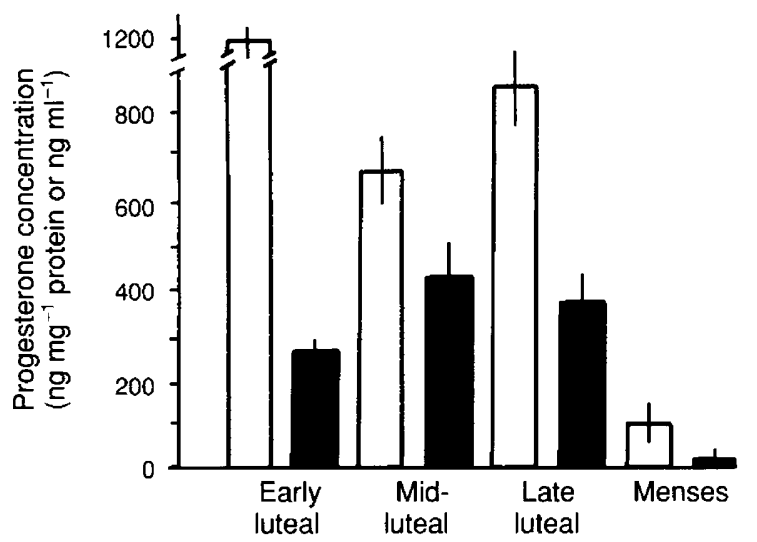

Fig. 1. Progesterone concentrations in the $(\square)$ corpus luteum and ( ovarian venous blood during the early luteal (days $4-6, n=6$ ), mid-luteal (days 7-9, $n=6$ ), late luteal (days 10-14,n=6) phases and at menses (days $15-16, n=5$ ) in control monkeys. Day 0 : day of preovulatory oestradiol surge. Results are expressed as means \pm SEM. Note that progesterone content of tissue from the early luteal phase is significantly higher $(P<0.01)$ than in tissue from other phases, while concentrations in ovarian venous blood are significantly lower $(P<0.05)$ during the early luteal phase than during the mid- or late luteal phase but higher than at menses.

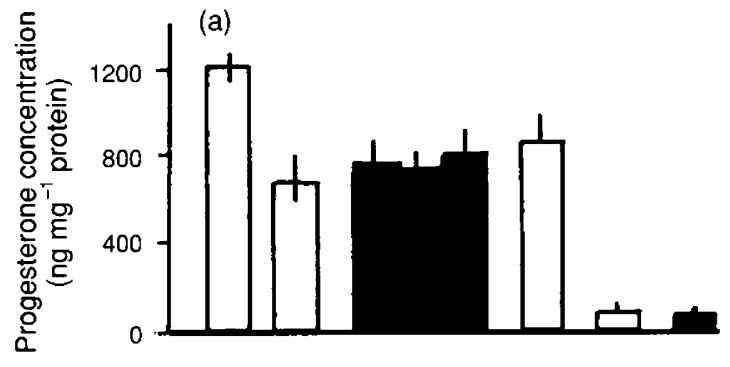

(b)

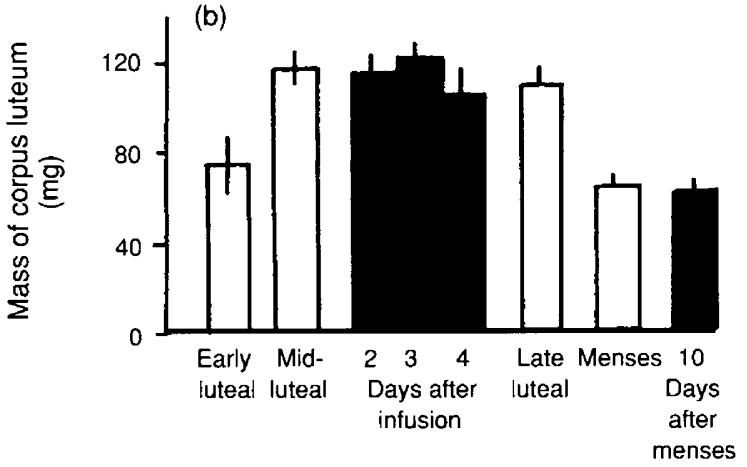

Fig. 2. (a) Luteal progesterone concentration and (b) mass of corpus luteum in $(\square)$ control monkeys at different stages of the luteal cycle compared with values following $(\boldsymbol{\square})$ vehicle infusion into the corpus luteum (measurements were taken 2, 3, 4, and at menses +10 days after infusion). Results are expressed as mean $\pm \mathrm{SEM}$. Vehicle infusion had no effect on progesterone content nor on luteal mass. Vehicle, +2 $(n=5),+3(n=4),+4(n=5)$, menses $+10(n=5)$.

contents kept frozen $\left(-20^{\circ} \mathrm{C}\right)$ until analyses of progesterone and protein. After thawing, the media and tissue were decanted and ground using glass homogenizers. Separate aliquots were
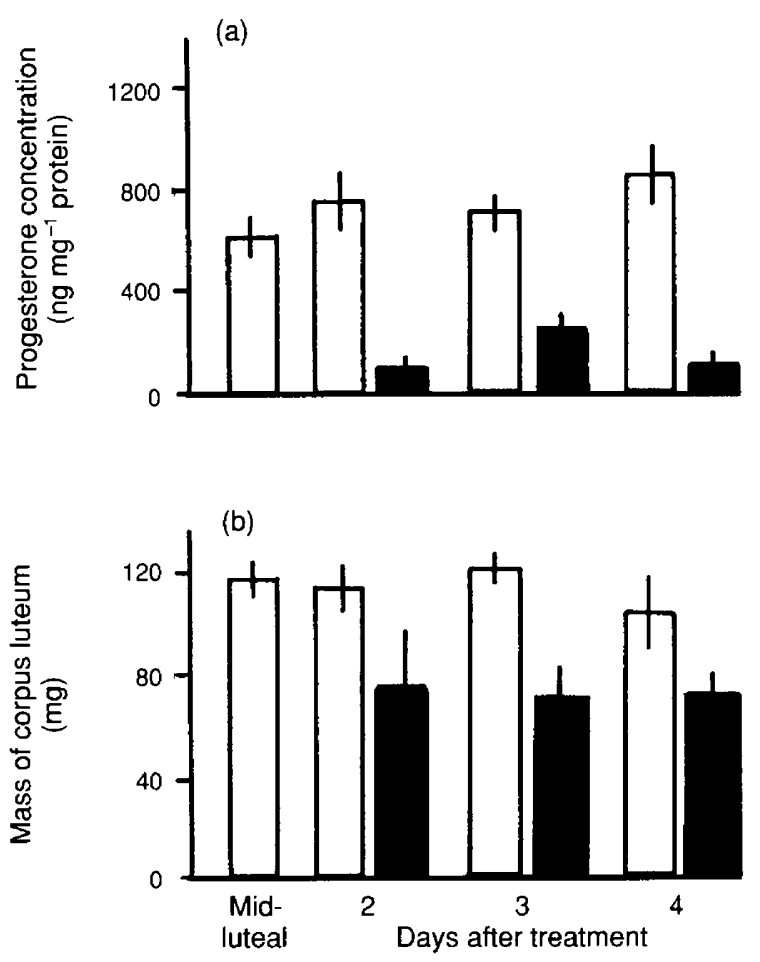

Fig. 3. (a) Luteal progesterone concentration and (b) mass of corpus luteum after infusion of $(\square)$ vehicle or $(\square) P \mathrm{PF}_{2 u}$ in the corpus luteum of monkeys. Measurements were taken 2, 3 and 4 days after beginning treatments. Results are expressed as means $\pm S \Xi M . \mathrm{PGF}_{2 \alpha}$ caused a significant decrease in luteal progesterone $(P<0.01)$ and luteal mass $(P<0.05)$ after 2 days of infusion. $\mathrm{PGF}_{2 u^{\prime}}+2(n=5),+3$ $(n=5),+4(n=4)$. Mid-luteal $n=5$.

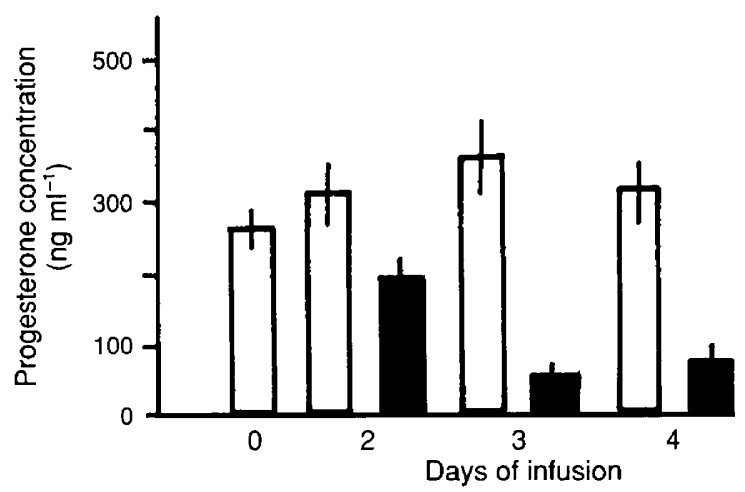

Fig. 4. Ovarian venous progesterone concentration (mean \pm SEM) after infusion of $(\square)$ vehicle or $(\square) P \mathrm{PGF}_{2 a}$ into the corpus luteum of monkeys. $\mathrm{PGF}_{2 a}$ caused a significant $(P<0.05)$ depression in ovarian vein progesterone after 2 days infusion, an effect that continued on days 3 and $4(P<0.01)$. Control: $n=14 ; 2$ days of infusion: $n=5 ; 3$ days of infusion: $n=5 ; 4$ days of infusion: $n=4$.

taken for progesterone and protein determinations. Results are expressed as ng progesterone $\mathrm{mg}^{-1}$ protein.

The dose of hCG and dibutyryl cAMP used was determined from dose-response curves generated from tissue obtained from the mid-luteal phase. The $\mathrm{ED}_{50}$ value for $\mathrm{hCG}$ was $10 \mathrm{iu}$ $(0-1000 \mathrm{iu})$ and for dibutyryl cAMP was $5 \mathrm{mmol} \mathrm{l^{-1 }}$ $\left(0-100 \mathrm{mmol} \mathrm{l}^{-1}\right)$. Doses of hCG and dibutyryl cAMP were 


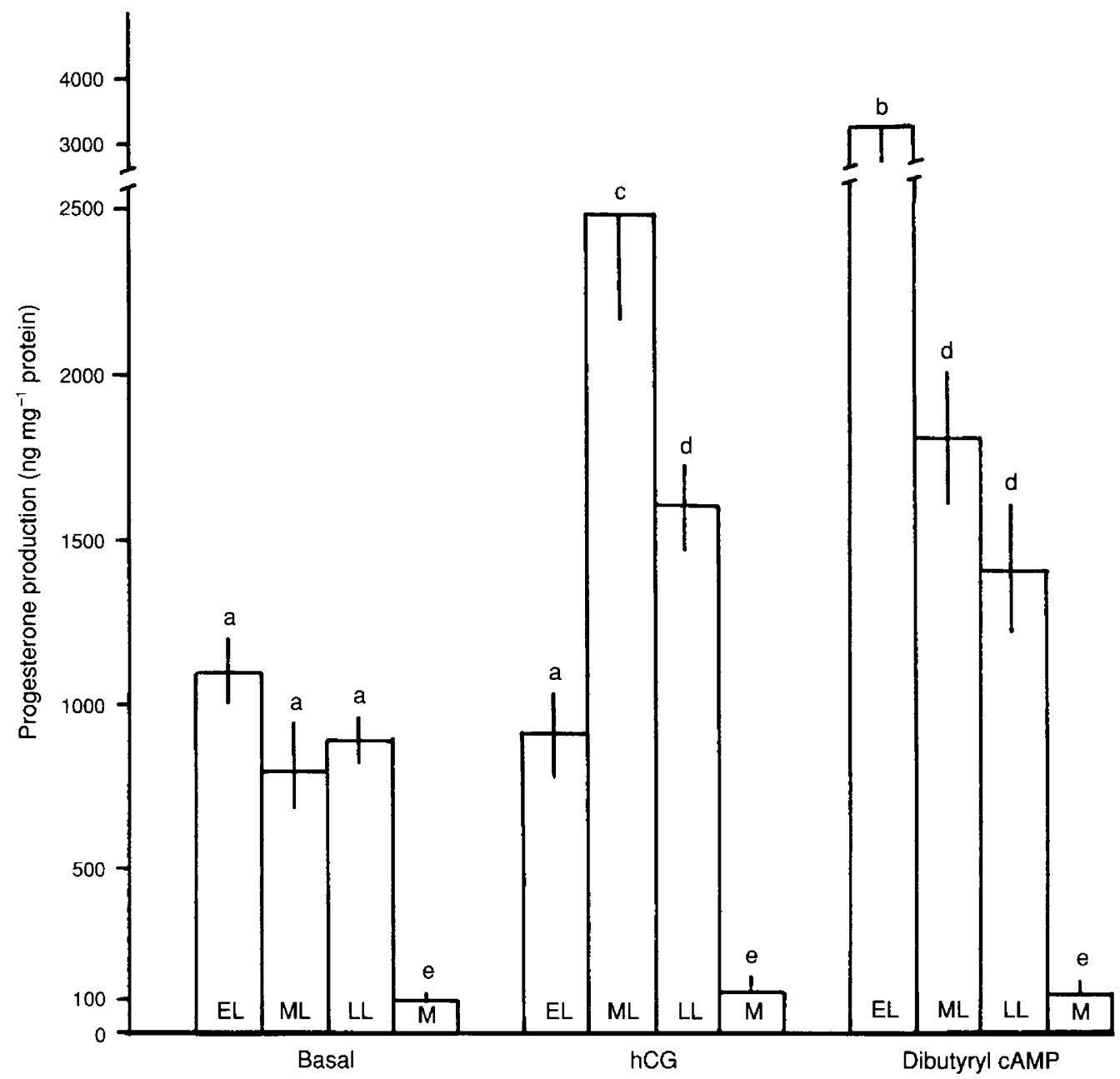

Fig. 5. Progesterone production (mean \pm SEM) by luteal tissue of monkeys in the presence of hCG (10 iu $\mathrm{ml}^{-1}$ ) or dibutyryl cAMP $\left(5 \mathrm{mmol} \mathrm{I}^{-1}\right)$. Early luteal (EL, days $\left.4-6, n=6\right)$, mid-luteal (ML, days $\left.7-9, n=6\right)$, late luteal (LL, days $10-14, n=6)$ and at menses $(M, n=5)$. Day 0 : day of preovulatory oestradiol surge. Means with different letters are significantly different: ${ }^{a}$ versus ${ }^{b}(P<0.001) ;{ }^{a}$ versus ${ }^{c}(P<0.01) ;{ }^{a}$ versus ${ }^{d}(P<0.05)$; ${ }^{a}$ versus ${ }^{\mathrm{e}}(P<0.01)$. hCG failed to stimulate progesterone during the early luteal phase; dibutyryl cAMP was stimulatory. Neither hCG nor dibutyryl cAMP enhanced progesterone production once menses had occurred. A progressive lack of responsiveness of the corpus luteum to hCG and dibutyryl cAMP was also observed.

similar to those used by Hamberger et al. (1979) and Dennefors et al. (1982). In incubations using luteal tissue from monkeys receiving $\mathrm{PGF}_{2 \alpha}$ treatment, only the response to $\mathrm{hCG}$ was assessed as there was insufficient tissue to evaluate both agents.

\section{Statistical analyses}

Results are expressed as means \pm SEM. Data were assessed using ANOVA. Differences in means were resolved by Duncan's new multiple-range test (Steel and Torrie, 1960). $P<0.05$ was considered significant.

\section{Results}

Luteal progesterone content and ovarian venous progesterone concentrations in control monkeys are given (Fig. 1). In the early luteal phase, progesterone was significantly higher
$(P<0.01)$ than in the other luteal phases; values were the same in the mid- and late luteal phases, whilst at menses, progesterone concentrations were significantly depressed $(P<0.01)$. The pattern of ovarian venous progesterone was opposite to that of tissue progesterone: blood concentrations were highest during the mid- and late luteal phases, while the highest tissue value was observed during the early luteal phase.

Luteal progesterone content and weight of the corpus luteum were not affected by infusion of vehicle alone (Fig, 2), indicating that the surgical procedure and vehicle infusion did not affect the biochemical or morphological integrity or function of the corpus luteum.

Treatment with $\mathrm{PGF}_{21}$ had significantly $(P<0.001)$ reduced tissue progesterone by day 2 of infusion and the effect persisted to day 4 (Fig. 3). Similarly, the mass of the corpus luteum was significantly reduced $(P<0.01)$ by day 2 . As with luteal progesterone and mass of the corpus luteum, blood 


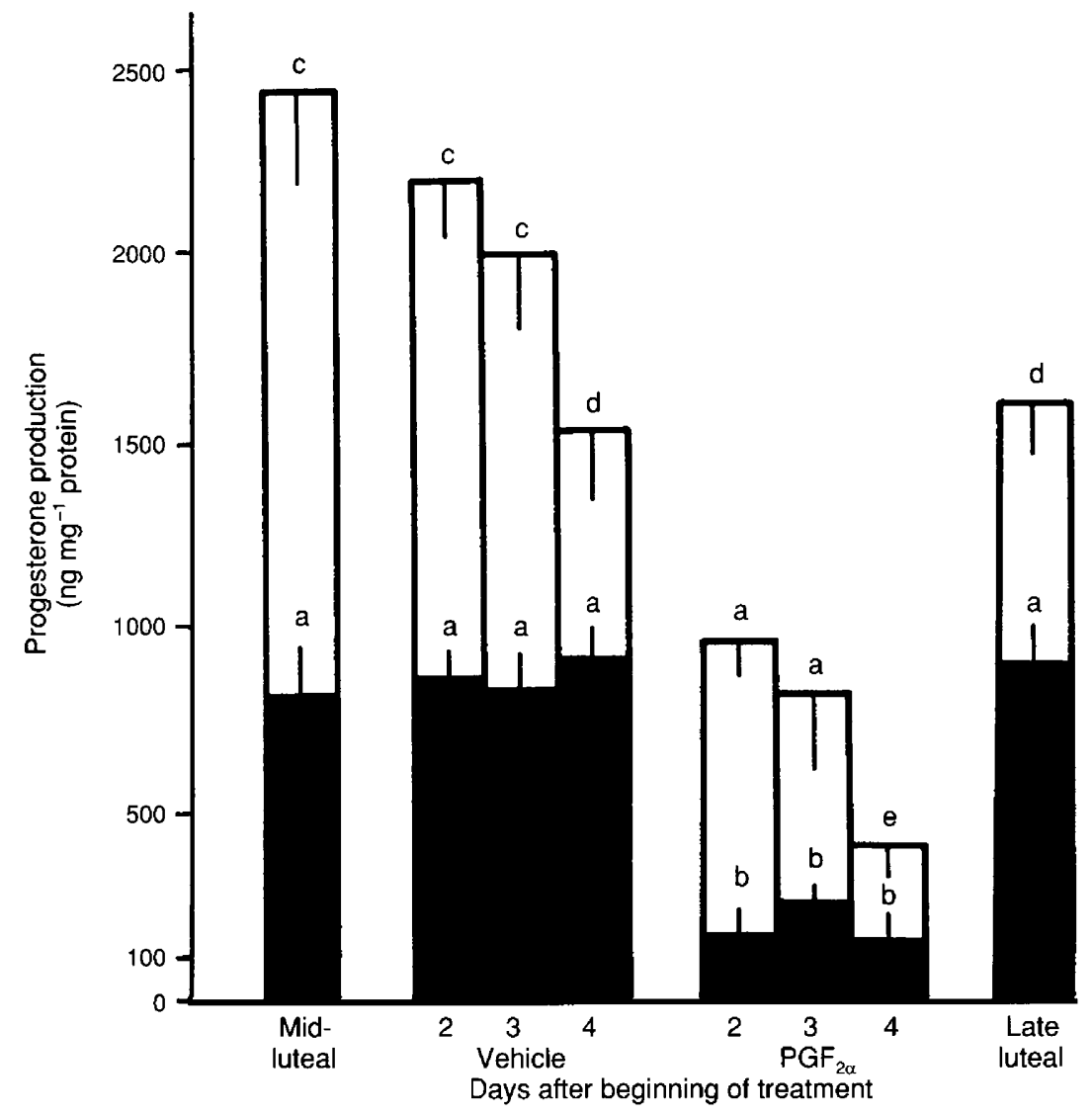

Fig. 6. Progesterone production (mean \pm SEM) by luteal tissue of monkeys in the presence of hCG (10 iu ml ${ }^{-1}$ ) after infusion of vehicle (tham buffer, $\left.1 \mu \mathrm{h} \mathrm{h}^{-1}\right)$ or $\mathrm{PGF}_{2 \alpha}\left(10 \mathrm{ng} \mu^{-1}\right.$ $\mathrm{h}^{-1}$ ) into the corpus luteum. (ם) Basal production. Mid-luteal and late luteal data are from Fig. 5. Means with different letters are significantly different: ${ }^{a}$ versus $^{b}:(P<0.01)$; ${ }^{a}$ versus ${ }^{c}:(P<0.01)$; ${ }^{a}$ versus ${ }^{\mathrm{d}}:(P<0.05) ;{ }^{a}$ versus ${ }^{e}:(P<0.05)$. There was a progressive lack of response by the corpus luteum to hCG with increased time of exposure to PGF $2 a^{\text {. }}$ $n:+2=5,+3=5,+4=4$; mid-luteal phase: $n=6$; late luteal phase: $n=6$.

concentrations of progesterone were significantly $(P<0.01)$ depressed after day 2 of $\mathrm{PGF}_{2 \omega}$ infusion, with further reductions $(P<0.001)$ by days 3 and 4 (Fig. 4).

When compared with basal values, hCG significantly $(P<0.01$ and 0.05 , respectively) stimulated progesterone production during the mid- and late luteal phases, but not during the early luteal phase nor at menses. Dibutyryl cAMP caused an increase in progesterone production in all phases of the cycle except at menses. These data also reveal a decreasing responsiveness to hCG and dibutyryl cAMP as the corpus luteum approaches luteal demise (Fig. 5). Tissue obtained at menses was always unresponsive to hCG and dibutyryl cAMP.

Progesterone production from corpora lutea undergoing vehicle infusion showed a similar response to hCG when compared with control tissue obtained during the mid- and late phases of the cycle (days 7-11); again, a decrease in response was observed on days 3 and 4 (Fig. 6). PGF $_{2 \mu}$ treatment caused a blunted effect when compared with the control. Even though basal values of progesterone were in the menses range (menses had not occurred), hCG could stimulate progesterone production in all $\mathrm{PGF}_{2 \alpha}$-exposed tissue, although a decreasing responsiveness to hCG was observed as a consequence of the duration of exposure to $\mathrm{PGF}_{2 u}$.

\section{Discussion}

It has been postulated that in primates, $\mathrm{PGF}_{2 \alpha}$ of ovarian, and probably of luteal, origin (Auletta et al., 1984b; Kauma et al., 1990) represents the physiological luteolysin (Auletta, 1990; Michael et al, 1994). The mechanism(s) of the luteolytic effect of PGF $_{2 \alpha}$ is not fuliy known.

Data presented in the study reported here reveal that the ability of the corpus luteum to synthesize progesterone as a consequence of gonadotrophin stimulation in vitro, after timed exposure to $\mathrm{PGF}_{2 "}$ in vivo, can be equated to the response observed from corpora lutea from control cycles. As the normal or vehicle-infused corpus luteum ages, there is a progressive decline in progesterone production after stimulation by hCG or dibutyryl cAMP. These observations suggest that luteolysis results from an incremental impairment in LH/hCG and cAMP receptor availability or function. This contention is further substantiated by the following observations: (i) every second day the production of hCG must at least double that present in the circulation to rescue and maintain the corpus luteum in early pregnancy (Atkinson et al., 1975; Lenton and Woodward, 1988); (ii) progressively, increasing doses of hCG, exogenously administered, can rescue and maintain the primate corpus 
luteum (Wilks and Noble, 1983; Auletta and Kelm, 1994), while the same dose given over several days will not (Knobil, 1980); and (iii) hCG always inhibits $\mathrm{PGF}_{2 \mathrm{a}}$-provoked luteolysis in vivo (Auletta and Kelm, 1994). In the last mentioned study, a decreased sensitivity of the corpus luteum to increasing hCG concentration was also observed, further suggesting that, as the corpus luteum matures, some modification occurs with the gonadotrophin receptor and with post-receptor events.

The progressive decline in progesterone production resulting from stimulation by hCG and dibutyryl cAMP in control and $\mathrm{PGF}_{2 \alpha}$-treated corpora lutea further suggests that loss or lack of availability of gonadotrophin receptors is not an abrupt event in luteolysis, but a continuous process during luteal ageing. Although progesterone concentrations were in the menses range after short-term exposure to $\mathrm{PGF}_{2 \alpha^{\prime}}$ hCG could still stimulate progesterone production. The relative changes in progesterone secretion after vehicle/PGF ${ }_{2 \alpha}$ treatment were virtually identical. However, the absolute concentrations were clearly different. The absence of hCG-stimulated progesterone production during the early luteal phase indicates a lack of availability of LH/hCG receptor, rather than a loss. This observation was also reported by Cameron and Stouffer (1982), who suggested that gonadotrophin receptor occupancy was maximal owing to the recent $\mathrm{LH}$ surge. The cAMP-mediated steroidogenic system is viable because dibutyryl cAMP caused an increase in progesterone at the same time.

The failure of $\mathrm{hCG}$ and dibutyryl cAMP to stimulate progesterone production from luteal tissue obtained at menses implies that once luteolysis is complete, the integrity of the steroidogenic machinery is unequivocally lost. This observation is in contrast to a report by Castracane (1993), who showed that exogenous, pharmacological doses of hCG administered to women during menses resulted in an increase in blood progesterone concentrations; although no attempt was made to verify the site of the progesterone production, it was assumed to arise from the recently demised corpus luteum.

The pattern of ovarian venous progesterone when compared with luteal tissue progesterone over the course of the luteal phase is initially diametric. During the early luteal phase, tissue concentrations of progesterone are at the highest of the entire luteal phase, while ovarian vein and peripheral (not shown) concentrations are at their lowest (excluding concentrations at menses). An explanation for this observation is that the blood supply to the corpus luteum has yet to be established (usually 4-5 days after ovulation, Corner, 1945); progesterone in the ovarian and peripheral vessels probably results from diffusion rather than from haemodynamics (Gibson et al., 1985). The corpus luteum is also refractory to pulsatile gonadotrophin stimulation at this time (Filicori, 1990).

These are the first investigations that compare progesterone concentrations in luteal tissue and in ovarian veins, and the responsiveness of normal and $\mathrm{PGF}_{2 u}$-treated corpora lutea to gonadotrophin and a cAMP analogue. These data strongly intimate a similarity between spontaneous and $\mathrm{PGF}_{2 a}$-induced luteal demise, and further strengthen the possibility of a physiological role for $\mathrm{PGF}_{2 \alpha}$ in primate luteolysis.

The authors thank the Andrew W. Mellon Foundation and the US Public Health Service (HD-15444) for their generous support. The authors extend their appreciation to D. Paradis and M. Wesley for their excellent technical assistance, K. Lilley and J. Hamlin for their secretarial help and P. Wooding and N. Kenny for their criticisms and suggestions.

\section{References}

Abayasekara DRE, Michael AE, Webley GE and Flint APF (1993) Mode of action of prostaglandin $F_{2, k}$ in human luteinized granulosa cells: role of protein kinase C Molecular and Cellular Endocrinology 97 81-91

Atkinson LE, Hotchkiss J, Fritz GR, Surve AH, Neill JD and Knobil E (1975) Circulating levels of steroids and chorionic gonadotropin during pregnancy in the rhesus monkey, with special attention to the rescue of the corpus luteum in early pregnancy Biology of Reproduction 12 335-345

Auletta FJ (1990) Paracrine regulation of luteal function. In Major Advances in Human Female Reproduction Serono Symposium 73 155-163 Eds EY Adhasi and S Mancuso. Raven Press, New York

Auletta FJ and Flint APF (1988) Mechanisms controlling corpus luteum function in sheep, cows, nonhuman primates and women especially in relation to the time of luteolysis Endocrine Reviews 9 88-105

Auletta FJ and Kelm LB (1994) Mechanisms controlling corpus luteum function in the rhesus monkey (Macaca mulatta): inhibitory action of hCG on luteolysis induced by PGF $_{2:}$ Journal of Reproduction and Fertility 102 215-220

Auletta FJ, Kamps DL, Pories S, Bisset J and Gibson M (1984a) An intra-corpus luteum site for the luteolytic action of prostaglandin $\mathrm{F}_{211}$ in the rhesus monkey Prostaglandins 27 285-298

Auletta FJ, Kamps DL, Wesley M and Gibson M (1984b) Luteolysis in the rhesus monkey: ovarian venous estrogen, progesterone, and prostaglandin $F_{2 \alpha^{-}}$ metabolite Prostaglandins 27 299-310

Balmaceda J, Asch RH, Fernandez EO, Eddy CA and Pauerstein CJ (1979) Prostaglandin production by the rhesus monkey corpora lutea in vitro Fertility and Sterility $31214-216$

Bradford MM (1976) A rapid and sensitive method for the quantitation of microgram quantities of protein utilizing the principle of protein-dye binding Analytical Biochemistry $72 \quad 248-254$

Cameron JL and Stouffer RL (1982) Gonadotropin receptors of the primate corpus luteum. III. Changes in available luteinizing hormone- and chorionic gonadotropin-binding sites in macaque luteal membranes during the nonfertile menstrual cycle Endocrinology 110 2068-2073

Castracane VD (1993) Direct and indirect effects of GnRH agonists on ovarian function Seminars in Reproductive Endocrinology 11 195-200

Corner GW (1945) Development, organization and breakdown of the corpus luteum in the rhesus monkey Contributions to Embryology 31 119-146

Dennefors BL, Sjogren A and Hamberger L (1982) Progesterone and adenosine $3^{\prime}, 5^{\prime}$-monophosphate formation by isolated human corpora lutea of different ages: influence of human chorionic gonadotropin and prostaglandins Journal of Clinical Endocrinology and Metabolism 55 102-107

Filicori M (1990) Maintenance of the corpus luteum of the menstrual cycle: hypothalamo-pituitary-ovarian axis Seminars in Reproductive Endocrinology 8 115-121

Gibson M, Samach A, Brumsted J and Auletta FJ (1985) Fate of peritoneal progesterone in the rabbit Steroids 46 735-740

Hamberger L, Dennefors B, Khan I and Sjogren A (1979) Cyclic AMP formation of isolated human corpora lutea in response to $\mathrm{hCG}$ - interference by PGF $_{2 u}$ Prostaglandins $17615-621$

Hearn JP and Webley GE (1987) Regulation of the corpus luteum of early pregnancy in the marmoset monkey: local interaction of luteotrophic and luteolytic hormones in vivo and their effects on the secretion of progesterone Journal of Endocrinology 114 231-239

Kauma SW, Curry TE, Jr, Powell DE and Clark MR (1990) Localization of prostaglandin endoperoxide synthase in the human corpus luteum Human Reproduction 5 800-804

Kenny N and Robinson J (1986) Prostaglandin $\mathrm{F}_{2 n}$-induced luteolysis: interactions of LH, prostaglandin $\mathrm{F}$ and forskolin in cyclic AMP and progesterone synthesis in isolated rat luteal cells Journal of Endocrinology 111 415-423

Knobil E (1980) The neuroendocrine control of the menstrual cycle Recent Progress in Hormone Research 36 53-88

Lenton EA and Woodward AJ (1988) The endocrinology of conception cycles and implantation in women Journal of Reproduction and Fertility Supplement 36 $1-15$ 
McCracken JA, Schramm W, Borcikowski B and Wilson L (1981) The identification of prostaglandin $\mathrm{F}_{2 \alpha}$ as a uterine luteolytic hormone in the sheep and the endocrine control of its synthesis Acta Veterinaria Scandinavica Supplementum $7771-88$

Michael AE, Abayasekara DRE and Webley GE (1993) The luteotropic actions of prostaglandins $\mathrm{E}_{2}$ and $\mathrm{F}_{20}$ on dispersed marmoset luteal cells are differentially mediated via cyclic AMP and protein kinase C Journal of Endocrinology 138 291-298

Michael AE, Abayasekara DRE and Webley GE (1994) Cellular mechanisms of luteolysis Molecular and Cellular Endocrinology 99 R1-R9

Neill JD, Johansson EDB and Knobil E (1969) Failure of hysterectomy to influence the normal pattern of cyclic progesterone secretion in the rhesus monkey Endocrinology 84 464-465

Richardson MC and Masson GM (1980) Progesterone production by dispersed cells from human corpus luteum: stimulation by gonadotropins and PGF $_{20}$; lack of response to adrenaline and isoprenaline Journal of Endocrinology 91 197-203

Steel RGD and Torrie JH (1960) Principles and Procedures of Statistics pp 80-115. McGraw-Hill, New York

Stouffer RL, Nixon WE and Hodgen GD (1977) Estrogen inhibition of basal and gonadotropin-stimulated progesterone production by rhesus monkey luteal cells Endocrinology 101 1157-1163
Stouffer RL, Nixon WE and Hodgen GD (1979) Disparate effects of prostaglandins on basal and gonadotropin-stimulated progesterone production by luteal cells isolated from rhesus monkeys during the menstrual cycle and pregnancy Biology of Reproduction 2 897-903

Summers PM. Wennick CJ and Hodges JK (1985) Cloprostenol-mediated luteolysis in the marmoset monkey (Callithrix jucchus) Journal of Reproduction and Fertility 73 133-138

Wilks JW (1980) Effect of (15S)-15-methyl-prostaglandin $\mathrm{F}_{2 a}$ methyl ester and estrogens upon the corpus luteum and conceptus of the rhesus monkey Prostaglandins 20 807-823

Wilks JW and Noble AS (1983) Steroidogenic responsiveness of the monkey corpus luteum to exogenous chorionic gonadotropin Endocrinology 112 1256-1266

Wilks JW, Forbes KK and Norland JF (1972) The prostaglandins. In Brook Lodge Symposium pp 47-58 Ed. EM Southern. Futura Publishing Co., Mt Kisco, NY

Zelinski-Wooten MB and Stouffer RL (1990) Intra-luteal infusions of prostaglandins of the E, D, I and A series prevent $\mathrm{PGF}_{2 \mathrm{u}}$-induced but not spontaneous, luteal regression in rhesus monkeys Biology of Reproduction $\mathbf{4 3}$ 507-516 